\title{
Current Trends on Natural Bioenhancers: A Review
}

\section{Chavhan SA*, Shinde SA and Gupta HN \\ Dr. Rajendra Gode College of Pharmacy, India}

*Corresponding author: Chavhan SA, Dr. Rajendra Gode College of Pharmacy, Malkapur Dist- Buldana (MS) - 443101, India, Tel: 9890321493; E-mail: sarinchavhan21@gmail.com

\section{Review Article}

Volume 2 Issue 1

Received Date: December 12, 2017

Published Date: January 05, 2018

\section{Abstract}

Bioenhancers are such agents, which by themselves are not therapeutic entities but when combined with an active drug lead to the potentiation of the pharmacologic effect of the drug. When any drug molecules are being introduced in every year but many of these molecules have problems like their solubility, stability, bioavailability and its long lasting side effects. Low bioavailability is one of the serious but curable problems in case of the drug molecule. There are some other factors also which responsible for low bioavailability i.e. low lipophilicity and zwitterionic character at physiological $\mathrm{pH}$, poor water solubility or efflux by P-glycoprotein (P-gp) etc. The object of this review is to explore the concept of bioavailability to achieve better therapeutic response in appropriate dose using natural drugs and natural products like ginger, caraway, aloe, quercetin, glycyrrhizin piperine, curcumin etc. The use of natural products is the most reliable means for bioavailability enhancement because these are safe, non-toxic, economical, easily procured, non-addictive, pharmacologically inert and non-allergenic in nature etc. Herbal bioenhancer are use for various categories of drug like neutraceuticals, antibiotics, antitubercular and anticancer and cardiovascular for immediate effects. Bioenhancers are recently used in many novel drug delivery formulations such as liposomes, transferosomes, ethosomes etc. This review explores the natural drugs from plant and animal sources with their mechanism, in-vivo study, marketed formulation and its future prospective. Researchers must solve these issues of drug toxicity to deliver a safe and effective dose of drugs to attain desired pharmacological response.

Keywords: P-glycoprotein; Prodrug; Piperine; Curcumin; Ginger

\section{Introduction}

Medicinal plants are major components of all indigenous or alternative systems of medicines like Ayurveda, Homeopathy, Naturopathy, Siddha, Unani, etc. Demand of herbal drug and natural plant based products is increase throughout the world due to nontoxic, no side effect, low cost and affordable available to poor [1,2]. Many synthetic and herbal drugs suffer from the problem of low bioavailability. Low membrane permeability is the major cause, lower lipophilicity, ionic characteristics, poor water solubility or P-glycoprotein. Bioavailability is the rate and 
extent to which a substance enters systemic circulation and becomes available at the required site of action [3]. Maximum bioavailability is attained by drugs administered via intravenous route, whereas drugs administered orally are poorly bioavailable as they readily undergo first pass metabolism and incomplete absorption. Such unutilized drug in the body may lead to adverse effects and also drug resistance. Thus, there is need of molecules which themselves have no same therapeutic activity but when combined with other drugs/molecules enhance their bioavailability. Many natural compounds from medicinal plants have capacity to augment the bioavailability when co-administered with another drug [4]. "The phenomenon of increasing the total availability of any chemical entity (nutrient or drug molecule) in biological fluid or systemic circulation is called biopotentiation or bioenhancement and the secondary agents which are responsible for this augmentation of plasma concentration of principle ingredient are termed as Biopotentiers or Bioavailability enhancers" [2].

Concept of biopotentiation was not so novel it has been so far used in old times by ayurvedic peoples so called as "Yogvahi" that meant to use herbs to increase or potentiates plasma concentration of drug. Piperine of black pepper was the first in this series as the major part of "Yogvahi". According to given in literature it is reveal that biopotentiator shows bioavailability enhancement if administered at lower dose with active ingredient and it do not introduce its own therapeutic action with the actual active principle at the therapeutic dose used. Piperine, naringin, quercetin, glycyrrhizin, genistein, sinomenine, nitrile glycoside and cow urine distillate have capability to augment and enhance the bioavailability. A augmentation of bioefficacy reduces dose, toxicity and adverse effects so in return shorten the time and cost of treatment. These concept covers drug categories like antibiotics, antitubercular and anticancer and cardiovascular which are so potent in nature and require quite immediate effects.

Bioenhancers are recently used in many novel drug delivery formulations such as liposomes, transferosomes, ethosomes etc [4].

\section{Ideal Properties of the Bioenhancers}

The contribution of bioenhancers have been reviewed which states that the ideal bioenhancers [5].

a) Should be nontoxic, non-allergenic and non-irritating.

b) Should not produce own pharmacological effects.

c) Should be rapid-acting with predictable and reproducible activity. d) Should be unidirectional in action.

e) Should be compatible with other active pharmaceutical ingredients.

f) Should be stable with time and environment.

g) Should be easily formulated into a various dosage form.

h) Should be easily available and cost effective.

\section{Concept of Bioavailability Enhancers}

The concept of bioavailability enhancer is derived from traditional old age Ayurveda black pepper; long pepper and ginger are collectively called as Trikatu. In Sanskrit Trikatu means Three acrids. The action of bioavailability enhancer was first discovered by Bose in 1929 who described the action of long pepper to adhatoda vasaka leaves which increased activity of vasaka [6].

The term bioavailability enhancer was first coined by Indian scientist at Regional Research lab. Jammu, who discovered and named piperine as world's first bioavailability enhancer in 1979 [6].

It offers comfortable, convenient, and noninvasive way to administer drugs due to following advantages of it.

a) Dose reduction

b) Minimization of drug resistance.

c) Minimization of drug (especially true in case of anticancer drug like taxol).

d) Ecological benefit.

e) Safety of the environment [5].

\section{Drug Absorption Barriers}

The drug must cross the epithelial barrier of the intestinal mucosa for it to be transported from the lumen of the gut into the systemic circulation and exert its biological actions. There are many anatomical and biological barriers for the oral drug delivery system to penetrate the epithelial membrane $[7,8]$. There are many structures in the intestinal epithelium which serve as barriers to the transfer of drugs from the gastrointestinal track to the systemic circulation. An aqueous stagnant layer due its hydrophilic nature is potential barrier to the absorption of drugs. The membranes around cells are lipid bilayers containing proteins such as receptors and carrier molecules. Drugs cross the lipid membrane by passive diffusion or carrier-mediated transport which involves the spending of energy. For the passage of small water-soluble molecules such as ethanol there are aqueous channels within the proteins. The drug molecules larger than about $0.4 \mathrm{~nm}$ face difficulty in passing through these aqueous channels [8]. 


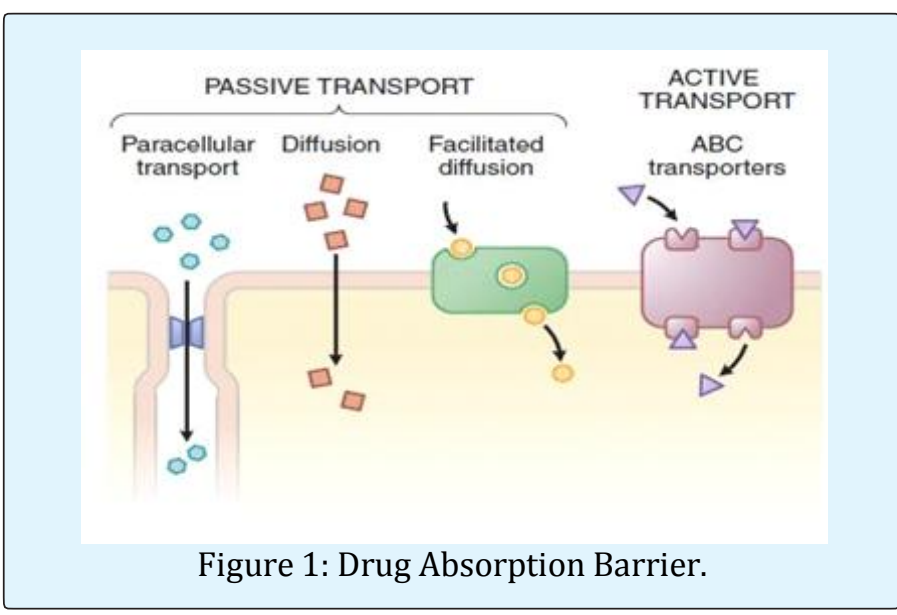

Recent work has shown that drug efflux pumps like Pgp possess very important role inhibiting efficient drug entry into the systemic circulation [9]. P-gp is a type of ATPase and an energy dependent transmembrane drug efflux pump it belongs to members of $\mathrm{ABC}$ transporters. It has a molecular weight of $-170 \mathrm{kDa}$ and has 1280 amino acid residues [10]. Since P-gp is gaining importance in absorption enhancement much work has still been made about its modulation due to its substrate selectivity and distribution at the site of drug absorption.

\section{Methods use to Enhance Absorption of Orally Administered Drugs}

There have been many approaches in use to enhance the intestinal absorption of poorly absorbed drugs. These approaches are as follows:

\section{Absorption Enhancers}

Many of the absorption enhancers are effective in improving the intestinal absorption, such as bile salts, surfactants, fatty acids, chelating agents, salicylates and polymers [11,12]. Chitosan, particularly trimethylated chitosan, increases the drug absorption via paracellular route by redistribution of the cytoskeletal F-actin, causing the opening of the tight junctions. Bile, bile salts and fatty acids are surfactants which act as absorption enhancers by increasing the solubility of hydrophobic drugs in the aqueous layer or by increasing the fluidity of the apical and basolateral membranes. Calcium chelators such as EGTA and EDTA enhances absorption by reducing the extracellular calcium concentration, leading to the disruption of cell-cell contacts [13].

\section{Prodrugs}

To enhance the drug absorption and bioavailability chemical modification of drugs to produce prodrugs and more permeable analogues has been widely studied as a useful approach. Various ampicillin derivatives are one of the well-known examples of increasing the lipophilicity of agents to enhance absorption of a polar drug by prodrug strategy [14]. Ampicillin due to its hydrophilic nature is only $30-40 \%$ absorbed from the gastrointestinal tract. By esterification of carboxyl group of ampicillin the prodrugs of ampicillin such as pivampicilline, bacampicilln and talampicillin were synthesized these prodrugs were more lipophilic than the parent compound following oral administration and they showed higher bioavailability in comparison with ampicillin.

\section{Dosage Form and Other Pharmaceutical Approaches}

Utilization of permeability-enhancing dosage forms is one of the most practical approaches to improve the intestinal absorption of poorly absorbed drugs. Various dosage formulations such as liposomes [15] and emulsions [16] enhanced the intestinal absorption of insoluble drugs. Particle size reduction such as micronization, nanoparticular carriers, complexation and liquid crystalline phases also maximize drug absorption $[17,18]$.

\section{P-glycoprotein Inhibitors}

The application of P-gp inhibitors in improving peroral drug delivery has gained special interest. Several studies to enhance oral bioavailability have demonstrated the possible use of P-gp inhibitors that reverse P-gp-mediated efflux in an attempt to improve the efficiency of drug transport across the epithelia. P-gp inhibitors influence metabolism, absorption, distribution, and elimination of Pgp substrates in the process of modulating pharmacokinetics [19].

\section{Mechanisms of Action of Herbal Bioenhancers}

Different herbal bioenhancers may have same or different mechanism of action. Nutritional bioenhancers enhance absorption by acting on gastrointestinal tract. Antimicrobial bioenhancers mostly act on drug metabolism process.

a) Reduction in hydrochloric acid secretion and increase in gastrointestinal blood supply.

b) Inhibition of gastrointestinal transit, gastric emptying time and intestinal motility.

c) Modifications in GIT epithelial cell membrane permeability.

d) Cholagogous effect.

e) Bioenergetics and thermogenic properties.

f) Suppression of first pass metabolism and inhibition of drug metabolizing enzymes and acids [20]. 


\section{Classification of Bioenhancers [4]}

Classification of bioenhancer according to source

Plant origin: Niaziridin, Cuminumcyminum, Carumcarvi, Stevia, Lysergol, Glycerrhizin, Ginger, Allicin, Aloe vera, Simomenine, genistein, 5-methoxy hydnocarpin etc.

Animal origin: Cow urine distillate.

\section{Classification of Bioenhancers Based on Mechanism of Action}

a) Inhibition of p-gp efflux pump and other efflux pump:

b) Example: Carumcarvi (Caraway), Genistein, Cuminumcyminum, naringin etc.

c) Suppressors of CYP-450 enzyme and its isoenzyme:

d) Example: narigin, gallic acid and its esters etc.

e) Regulators of GIT function to facillated better absorption:

f) Examples: Aloevera (aloe), niaziridin (drumstick pods), zingiberofficinale (ginger), etc [20].

Bioenhancers from Herbal Sources

\begin{tabular}{|c|c|c|c|c|c|}
\hline \begin{tabular}{|c|} 
Sr.n \\
o. \\
\end{tabular} & Drug & Biological source & Mechanism & $\begin{array}{c}\text { Dose of } \\
\text { drug }\end{array}$ & Drug \\
\hline 1 & $\begin{array}{c}\text { Piperine } \\
\text { (1-piperoy } \\
\text { piperidine) }\end{array}$ & Piper longum & $\begin{array}{l}\text { Methylenedioxyphenyl ring in } \\
\text { piperine helps in the inhibition of } \\
\text { the drug metabolizing enzymes } \\
\text { including CYP } 450 \text { enzymes and } \\
\text { UDP glucuronyl transferase. It } \\
\text { also inhibits P-GP and then efflux } \\
\text { of absorbed drug from enterocytes }\end{array}$ & $15 \mathrm{mg} / \mathrm{kg}$ & $\begin{array}{c}\text { Piperine is used in combination } \\
\text { with various drugs and increases } \\
\text { the efficacy of these drugs }\end{array}$ \\
\hline 2 & Curcumin & $\begin{array}{l}\text { Dried and fresh rhizomes } \\
\text { of Curcuma longa Linn. } \\
\text { Family-Zingiberaceae. }\end{array}$ & \begin{tabular}{|c|} 
Curcumin suppresses drug \\
metabolizing enzymes (CYP3A4) \\
in the liver as well as inducing \\
changes in the drug transporter \\
P-glycoprotein, hence increase the \\
Cmax and AUC of celiprolol and \\
midazolam in rats
\end{tabular} & $12 \mathrm{~g} /$ day & Celiprolol and Midazolam \\
\hline 3 & $\begin{array}{l}\text { Ginger } \\
\text { (Whole } \\
\text { Part) }\end{array}$ & $\begin{array}{l}\text { Rhizome of the perennial } \\
\text { plant Zingiber officinale } \\
\text { Roscoe, Family- } \\
\text { Zingiberaceae. }\end{array}$ & $\begin{array}{l}\text { Due to the presence of saponins, } \\
\text { flavonoids, and alkaloids, Ginger } \\
\text { acts powerfully on GIT mucous } \\
\text { membrane. The role of ginger is } \\
\text { to regulate intestinal function to } \\
\text { facilitate absorption. }\end{array}$ & $\begin{array}{c}1-55 \mathrm{mg} \\
/ \mathrm{kg}\end{array}$ & $\begin{array}{c}\text { Antibiotics, antifungal, antiviral } \\
\text { and anticancerous drugs. } \\
\text { Therapeutic activity of Anti-TB } \\
\text { drugs like Rifampicin, } \\
\text { Pyrazinamide and Isoniazid }\end{array}$ \\
\hline 4 & $\begin{array}{c}\text { Caraway } \\
\text { (Seeds) }\end{array}$ & $\begin{array}{l}\text { Dried ripe seeds of Carum } \\
\text { carvi Linn., Family- } \\
\text { Umbelliferaceae. }\end{array}$ & $\begin{array}{l}\text { Due to a novel flavonoid glycoside } \\
\text { it enhances the peak concentration } \\
\text { (Cmax) and area under the curve } \\
\text { (AUC) of rifampicin }\end{array}$ & $1-55 \mathrm{mg} / \mathrm{kg}$ & $\begin{array}{l}\text { Antibiotics, antifungal, antiviral } \\
\text { and anticancerous drugs. } \\
\text { Therapeutic activity of Anti-TB } \\
\text { drugs like Rifampicin, } \\
\text { Pyrazinamide and Isoniazid. }\end{array}$ \\
\hline
\end{tabular}




\begin{tabular}{|c|c|c|c|c|c|}
\hline 6 & $\begin{array}{c}\text { Indian aloe } \\
\text { (Leaves) }\end{array}$ & \begin{tabular}{|l} 
pried juice of the leaves of \\
Aloe barbadensis Mill., \\
Family-Liliaceae
\end{tabular} & $\begin{array}{l}\text { longer in the plasma and increases } \\
\text { bioavailability of Vitamin C and } \mathrm{E} \\
\text { in human. It also capable of } \\
\text { inhibiting the release of reactive } \\
\text { oxygen free radicals from } \\
\text { activated human neutrophils. }\end{array}$ & & Vitamin $\mathrm{C}$ and $\mathrm{E}$ \\
\hline 7 & Quercetin & \begin{tabular}{|c|} 
It is a flavonoid found in \\
many fruits (apples, citrus \\
fruits like red grapes, \\
raspberries, and \\
cranberries), green leafy \\
vegetables and black and \\
green tea
\end{tabular} & $\begin{array}{l}\text { It inhibits the p-glycoprotein } \\
\text { efflux pump and metabolizing } \\
\text { enzyme, CYP 3A4 in the intestinal } \\
\text { mucosa and restraint the } \\
\text { metabolizing enzyme CYP3A4 }\end{array}$ & I & $\begin{array}{l}\text { Diltiazem, Digoxin, Epigallocate- } \\
\text { chin gallate }\end{array}$ \\
\hline 8 & Allicin & $\begin{array}{l}\text { Aromatic bulb of Allium } \\
\text { sativum Linn. Family- } \\
\text { Liliaceae }\end{array}$ & $\begin{array}{c}\text { Allicin enhances AmB-induced } \\
\text { vacuole membrane damage by } \\
\text { inhibiting ergosterol trafficking } \\
\text { from the plasma membrane to the } \\
\text { vacuole membrane }\end{array}$ & $\begin{array}{c}120 \mu \mathrm{M} \\
\text { allicin or a } \\
\text { non-lethal } \\
\text { concentrati } \\
\text { on of AmB } \\
(0.5 \mu \mathrm{M}) \\
\end{array}$ & $\begin{array}{l}\text { Fungicidal activity of } \\
\text { Amphotericin B }\end{array}$ \\
\hline 9 & Naringin & $\begin{array}{c}\text { It is a flavanone-7-O- } \\
\text { lycoside occurs naturally } \\
\text { in citrus fruits, especially } \\
\text { in grapefruit }\end{array}$ & $\begin{array}{l}\text { It inhibits the CYP3A } 1 / 2 \text { enzymes } \\
\text { and p-glycoprotein is modulated in } \\
\text { rats }\end{array}$ & $\left\{\begin{array}{c}3.3 \text { and } 10 \\
\mathrm{mg} / \mathrm{kg}\end{array}\right.$ & Paclitaxel, Verapamil, Diltiazem \\
\hline 10 & $\begin{array}{c}\text { Tea } \\
\text { (Leaves } \\
\text { and Buds) }\end{array}$ & \begin{tabular}{|l} 
Leaves and leaf buds of \\
Thea sinensis Linn. \\
Family- Theaceae
\end{tabular} & $\begin{array}{c}\text { The thermogenic properties of tea } \\
\text { extract shows a synergistic } \\
\text { interaction between caffeine and } \\
\text { catechin polyphenols that } \\
\text { appears to prolong sympathetic } \\
\text { stimulation of thermogenesis. } \\
\text { Green tea also promotes fat } \\
\text { oxidation and decreased the } \\
\text { absorption rate of zinc while black } \\
\text { tea }\end{array}$ & - & $\begin{array}{c}\text { Both teas promote the } \\
\text { absorption of manganese and } \\
\text { copper as nutrients in the blood } \\
\text { circulation. }\end{array}$ \\
\hline 11 & Niaziridin & $\begin{array}{c}\text { Niaziridin a nitrile } \\
\text { glycoside is isolated from } \\
\text { the pods of Moringa } \\
\text { oleifera Lam., Family- } \\
\text { Moringaceae }\end{array}$ & $\begin{array}{l}\text { Commonly act with antibiotics } \\
\text { against gram-positive bacteria like } \\
\text { Myobacterium smegmatis, Bacillus } \\
\text { pubtilis and gram-negative bacteria } \\
\text { like E. coli to increase the } \\
\text { absorption of it. }\end{array}$ & 要 & $\begin{array}{l}\text { Vitamin B12, rifampicin, } \\
\text { ampicillin, nalidixic acid, azole } \\
\text { antifungal drugs such as } \\
\text { clotrimazole }\end{array}$ \\
\hline 12 & Lysergol & \begin{tabular}{|} 
It is isolated from higher \\
plants like Rivea \\
corymbosa Linn., Ipomoea \\
violacea Linn. and \\
Ipomoea muricata Linn.
\end{tabular} & $\begin{array}{l}\text { It promotes the killing activities of } \\
\text { different antibiotics on bacteria. } \\
\text { lysergol enhances the transport } \\
\text { of antibiotics across the intestinal } \\
\text { gut and cell membrane. }\end{array}$ & $10 \mu \mathrm{g} / \mathrm{ml}$ & Broad-spectrum antibiotics \\
\hline 13 & Genistein & $\begin{array}{c}\mathrm{t} \text { is an isoflavone found in } \\
\text { a number of dietary } \\
\text { plants like soybean } \\
\text { (Glycine max Linn.) and } \\
\text { kudzu (Pueraria lobata } \\
\text { Willd.). }\end{array}$ & $\begin{array}{l}\text { Genistein is reported to be able to } \\
\text { inhibit P-gp, BCRP and MRP-22 } \\
\text { efflux functions }\end{array}$ & $\begin{array}{l}3.3 \mathrm{mg} / \mathrm{kg} \\
\mathrm{pr} 10 \mathrm{mg} / \mathrm{kg}\end{array}$ & $\begin{array}{l}\text { Paclitaxel, Epigallocatechin } \\
\text { gallate the }\end{array}$ \\
\hline
\end{tabular}




\begin{tabular}{|c|c|c|c|c|c|}
\hline 14 & $\begin{array}{c}\text { Sinomenin } \\
\mathrm{e}\end{array}$ & $\begin{array}{l}\text { Root of the climbing plant } \\
\text { Sinomenium } \\
\text { acutumThunb. Family- } \\
\text { Menispermaceae. }\end{array}$ & $\begin{array}{l}\text { The mechanism underlying the } \\
\text { increase in bioavailability of } \\
\text { paeoniflorin is explained as } \\
\text { sinomenine could decrease the } \\
\text { efflux transport of paeoniflorin by } \\
\text { P-gp in the small intestine. This } \\
\text { combination can be useful in the } \\
\text { treatment of inflammation and } \\
\text { arthritic }\end{array}$ & $90 \mathrm{mg} / \mathrm{kg}$ & Paeoniflorin \\
\hline 15 & $\begin{array}{l}5^{\prime} \text { methoxy } \\
\text { hydnocarp } \\
\text { n (5'-MHC) }\end{array}$ & $\begin{array}{c}\text { Leaves of Barberis } \\
\text { fremontii Torr., Family- } \\
\text { Berberidaceae. }\end{array}$ & \begin{tabular}{|c|}
$5^{\prime}$-MHC has no antimicrobial \\
activity but it inhibits the MDR- \\
dependent efflux of berberine \\
from $S$. aureus cells and effectively \\
disabled the bacterial resistance \\
mechanism against the berberin \\
antimicrobial action.
\end{tabular} & $100 \mu \mathrm{g} / \mathrm{ml}$ & Berberin \\
\hline 16 & $\begin{array}{c}\text { Hydnocarp } \\
\text { oic acid }\end{array}$ & $\begin{array}{c}\text { Seeds of Hydnocarpus } \\
\text { wightiana Family- } \\
\text { Achariaceae. }\end{array}$ & $\begin{array}{l}\text { It acts by blocking the synthesis } \\
\text { and coenzymatic activity of biotin. }\end{array}$ & $4 \mu \mathrm{g} / \mathrm{ml}$ & Biotin \\
\hline 17 & Stevia & $\begin{array}{l}\text { Leaves of Stevia } \\
\text { rebaudiana Bertoni., } \\
\text { Family- Asteraceae. }\end{array}$ & $\begin{array}{c}\text { Components of stevia called } \\
\text { Stevioside and steviol stimulates } \\
\text { insulin secretion via a direct } \\
\text { action on beta cells. Due to the } \\
\text { activity for reducing vascular } \\
\text { tension it is used for patients with } \\
\text { hypertension. }\end{array}$ & $30 \mathrm{mg} / \mathrm{kg}$ & $\begin{array}{c}\text { Antibiotics, antiobese drugs, } \\
\text { antidiabetic drugs, antifungal } \\
\text { drugs, antiviral drugs, anticancer } \\
\text { drugs, cardiovascular drugs, } \\
\text { anti-inflammatory, antiarthritic } \\
\text { agents, antituberculosis/ } \\
\text { antileprosy drugs, } \\
\text { anthelmintic/respiratory drugs, } \\
\text { immune-modulators, antiulcer } \\
\text { drugs, and herbal products or } \\
\text { drugs. }\end{array}$ \\
\hline 18 & Capsaicin & $\begin{array}{l}\text { Fruit of Capsicum annum } \\
\text { Linn., Family- Solanaceae }\end{array}$ & $\begin{array}{l}\text { The absorption of capsicum } \\
\text { increases AUC of the drugs. }\end{array}$ & - & Theophylline \\
\hline 19 & $\begin{array}{l}\text { Cumin } \\
\text { seeds }\end{array}$ & $\begin{array}{c}\text { Dried seeds of Cuminum } \\
\text { cyminum Linn., Family- } \\
\text { Apiaceae }\end{array}$ & $\begin{array}{c}\text { Possible mechanisms may be the } \\
\text { Aqueous extract of cumin seeds } \\
\text { stimulate } \beta \text {-adrenoceptors and/or } \\
\text { inhibit histamine H1 receptors. It } \\
\text { also worked in the opening of } \\
\text { potassium channels and inhibition } \\
\text { of calcium channels. }\end{array}$ & $\begin{array}{c}0.5 \text { to } 25 \\
\mathrm{mg} / \mathrm{kg}\end{array}$ & $\begin{array}{c}\text { Erythromycin, Cephalexin, } \\
\text { Amoxycillin, Fluconazole, } \\
\text { Ketoconazole, Zidovudine and 5- } \\
\text { Fluorouracil }\end{array}$ \\
\hline 20 & Ammaniol & \begin{tabular}{|} 
Methanolic extract of \\
Ammannia multiflora \\
Roxb., Family-Lythraceae
\end{tabular} & $\begin{array}{l}\text { Ammaniol have the property to } \\
\text { increase glucose uptake and shows } \\
\text { potent antihyperglycemic activity. }\end{array}$ & - & $\begin{array}{l}\text { Antimicrobial drugs like } \\
\text { Nalidixic acid }\end{array}$ \\
\hline 21 & Gallic acid & $\begin{array}{l}\text { Gallic acid is a type of } \\
\text { phenolic acid, found in } \\
\text { gallnuts, tea leaves and }\end{array}$ & $\begin{array}{c}\text { Gallic acid increases net drug } \\
\text { absorption and decrease drug } \\
\text { biotransformation in the gut wall }\end{array}$ & - & $\begin{array}{l}\text { Acetanilides, Aminoquinolines, } \\
\text { Benzodiazepines, benzofurans, } \\
\text { cannabinoids, digitalis }\end{array}$ \\
\hline
\end{tabular}




\begin{tabular}{|l|l|c|c|}
\hline oak bark etc. & $\begin{array}{c}\text { by inhibiting cytochrome P450 } \\
\text { drug metabolism preference in } \\
\text { other locations, such as the liver, } \\
\text { which was the primary site of } \\
\text { drug metabolism. }\end{array}$ & $\begin{array}{c}\text { glycosides, ergot alkaloids, } \\
\text { flavonoids, imidazoles, } \\
\text { quinolines, macrolides, } \\
\text { naphthalenes, opiates, oxazoles, } \\
\text { phenylalkylamines, piperidines, } \\
\text { polycyclic aromatic } \\
\text { hydrocarbons, pyrrolidines, } \\
\text { pyrrolidinones, stilbenes, } \\
\text { pulfonylureas, sulfones, triazoles, } \\
\text { tropanes and vinca alkaloids. }\end{array}$ \\
\hline
\end{tabular}

Table1: Herbs, its source, mechanism and their dose as bioenhances [5,21-35].

\section{Medicinal Plants as Bioenhancers}

\section{Piperine}

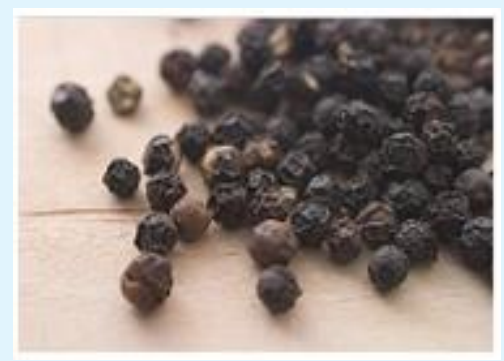

Figure 2: Piper nirgum.
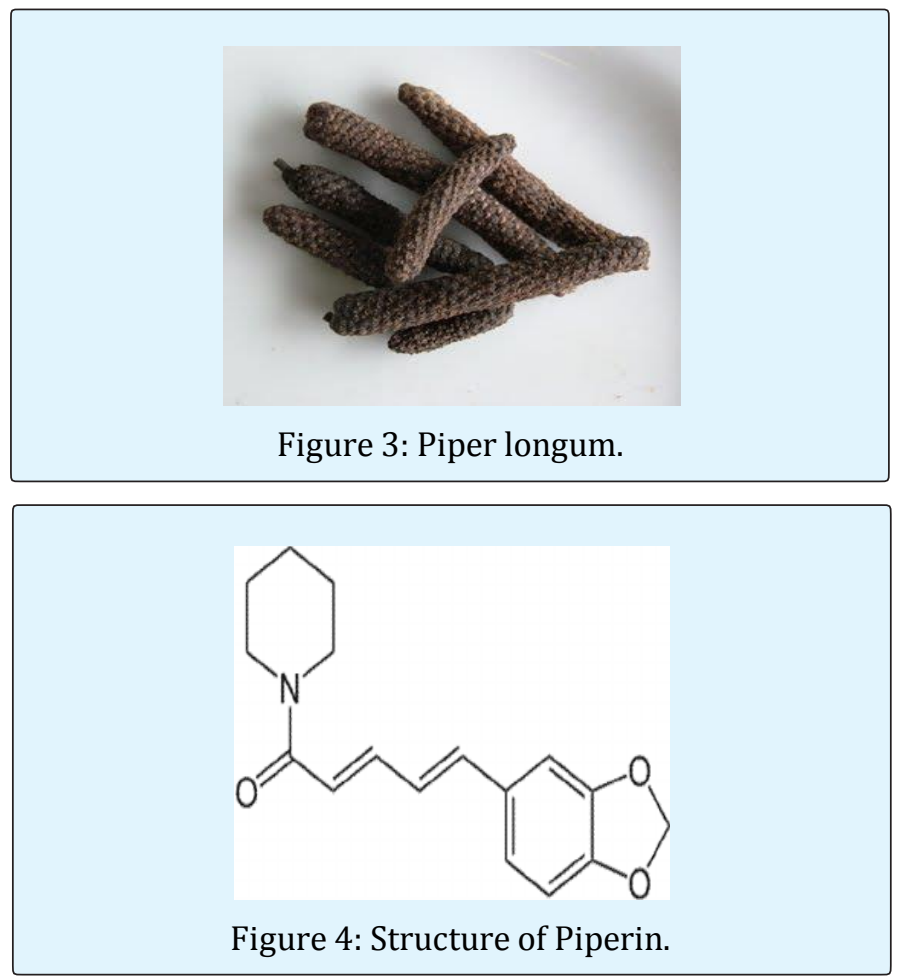

Piperine is primitive alkaloid which is mile stone for the field of biopotentiation. Chemically it is 1-piperoyl piperidine. It is obtained from Piper nigrumor Piper longum whether from stem, pods or leaf part. Piperine is generally regarded as safe (GRAS) by FDA authority. Activity of piperin is due to the conjugated double bonds in side chain part. Normal dose of piperine is approximately $15-20 \mathrm{mg} / \mathrm{kg}$ for a in a day.

Metabolic Enzymes: Piperine interacts and interferes both in vitro and in vivo with the metabolism and degradation related enzymes Studies have proved it as a nonspecific inhibitor of drug metabolism. Piperine inhibited number of enzymes in a series mainly related to P-gp and cytochrome P 450 family [36,37].

It includes others also like:

a) Aryl hydrocarbon hydroxylase (Microsomal enzyme system)

b) Ethyl morphine-N demethylatse

c) 7-Ethoxycoumarin-0-de-ethylase

d) Uridine di phosphate glucose dehydrogenase

e) Uridine di phosphate glucose dehydrogenase (UDP-GD)

f) Uridine di phosphate glucuronyltransferase (UDP-GT)

g) 5-Lipoxegenase (5-LOX)

h) Cyclo-oxegenase-I (COX-I)

\section{Antitubercular and Antileprotic Drugs}

The bioenhancing property of piperine was first utilized in the treatment of tuberculosis in human. Rifampin or Rifampicin is the drug of first line treatment in tuberculosis and leprosy. Piperin is so much useful for lowering the dose profile and shortening the treatment. Piperine was found to increase the bioavailability of rifampicin by about $60 \%$ and hence reduce the dose from 450 to 200mgRifampin acts on RNA polymerase and inhibits the transcription of the polymerase in human cells which is actually being catalyzed by Mycobacterium smegmatis. Piperine augments this activity of rifampin by several folds against RNA polymerase Piperine also stimulates the binding ability of rifampin to RNA polymerase even in resistant strains $[38,39]$. 


\section{Antibiotics}

The consumption of antibiotics and antimicrobials are increasing at very high rate that has cause most of immune system resistance or addicted for them. Patients have to take high dose of such drugs due to reduction in GIT absorption, uptake by pathogens and cells has decreased due to resisting efflux pumps. The major portion of the target dose remains as garbage in body fluids having no therapeutic use but causing drug resistance with time. Flouroquinolones and piperine in rabbits has shown augmented bioavailability due to piperin inhibits the Pglycoprotein efflux pump [40].

\section{Chemoprevention and Immunomodulatory}

Piperine reduces the aflatoxins that are responsible for several cytotoxic effects by inhibiting CYP-P450-mediated biological activation of mycotoxins into harmful ones [41]. It inhibits the lipid peroxidation phenomena so it modifies the oxidative changes in cells that results in free radicals scavenging activity [42]. It causes reduction in damage of
DNA and DNA proteins. The antiapoptotic property of piperin is attributed induction of Heme-oxygenase-1. It contains pentacyclicoxindole group in it which is responsible for all these activities [43].

\section{Nutraceuticals}

It also acts as a nutritional bioenhancer which enhances bioavailability and absorption of nutrients by acting on gastrointestinal tract (Table 2). In a double blind cross over studies it has been revealed that herbal supplementation can increase the concentration of vitamins against placebo by $50-60 \%$. Study suggests augmentation is due to the nonspecific mechanism \& thermogenic properties of piperine $[44,45]$.

Piperine also showed enhanced bioavailability when combined with Nevirapine, a potent non-nucleoside inhibitor of HIV-1 reverse transcriptase which is used in combination with other antiretroviral agents for the treatment of HIV-1 infection.

\begin{tabular}{|c|c|c|}
\hline Drug & Clinical model & Experimental assumption of action \\
\hline Curcuminoids & rats and human subjects & $\begin{array}{c}\text { Curcumin gets rapidly metabolised by liver and gut } \\
\text { enzymes. Piperine increase the bioavaibility about } 200 \% \\
\text { the effect is due to inhibition of hepatic and intestinal } \\
\text { glucoronidation. }\end{array}$ \\
\hline $\mathrm{EGCG}^{*}$ (green tea) & In albino mice & $\begin{array}{c}\text { This polyphenol showed chemopreventive activity animal } \\
\text { models but with piperine activity of drug has increased by } \\
1.3 \text { times in compared to normal treated. mechanism works } \\
\text { behind this concept is inhibition of glucuronidation and } \\
\text { gastrointestinal transit time }\end{array}$ \\
\hline Coenzyme & Double bind cross over & $\begin{array}{c}\text { Supplementation of piperine with coenzyme for long time } \\
\text { or at a high dose only can increase the bioavailability. It is } \\
\text { assumed that piperine follows nonspecific thermogenic or } \\
\text { bioenergetics propertics for augmentation }\end{array}$ \\
\hline
\end{tabular}




\begin{tabular}{|c|c|c|}
\hline $\begin{array}{c}\text { Pentazocine ( central } \\
\text { analgesic) }\end{array}$ & In albino mice tail flick method & $\begin{array}{c}\text { drug in plasma. Co-administration can relieve the pain 1.5 } \\
\text { times faster. }\end{array}$ \\
\hline Fexofenadine & $\begin{array}{c}\text { Piperine combined with pentazocine showed significant } \\
\text { increase in tail flick latency in comparison with } \\
\text { pentazocinealone and control group follows same } \\
\text { mechanism as with peripheral drugs }\end{array}$ \\
\hline Human Caco2 cells line \& male SD \\
rats
\end{tabular}$\quad$\begin{tabular}{c}
$\begin{array}{c}\text { Bioavailability can be increased up to 2- 3times than alone } \\
\text { drug. This action of biopotentiation is due to inhibition of P. } \\
\text { glycoprotein efflux pumps and delayed gastric emptying. }\end{array}$ \\
\hline
\end{tabular}

Table 2: Piperine also increases the bioavailability of curcumin, the active principle of Curcuma longa (turmeric).

\section{Turmeric:}
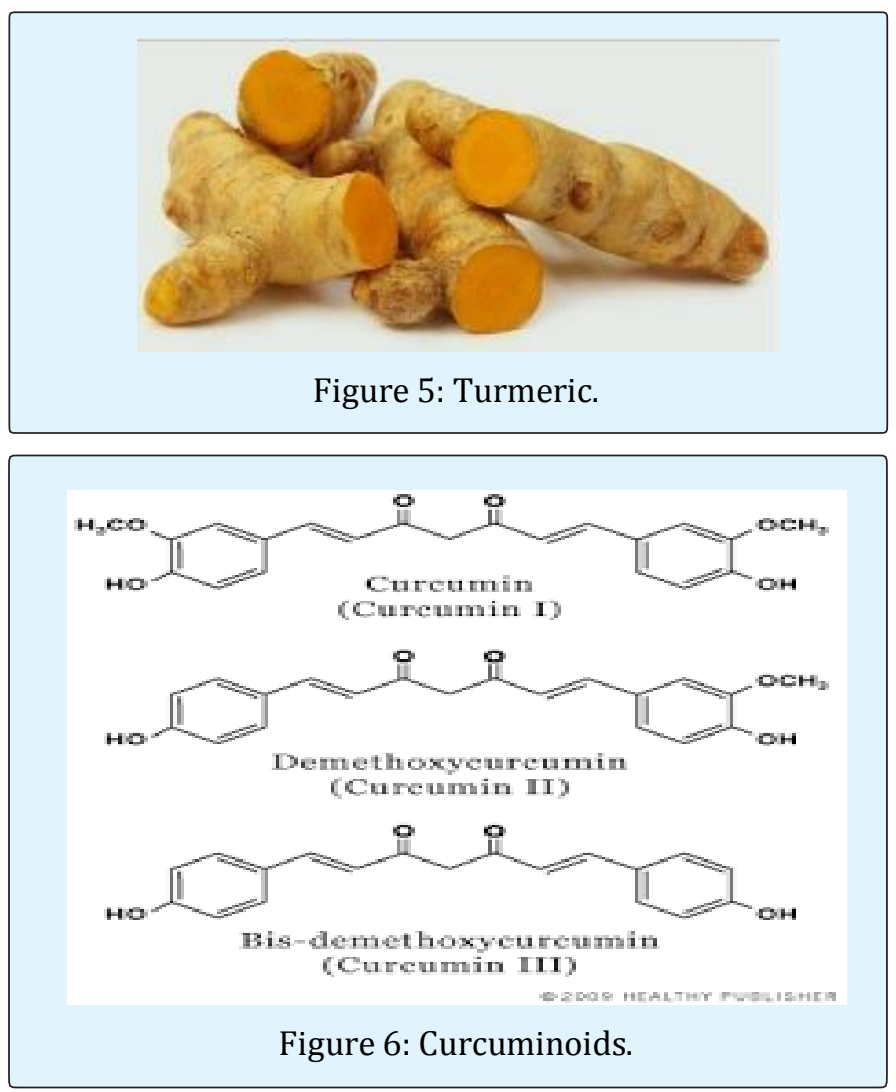

\section{Biological source}

It consists of dried as well as fresh rhizomes of plant known as Curcuma Longa, Family-Zingiberaceae. Turmeric (Curcuma longa) is a common household item used as remedy for various ailments. Curcumin, a flavonoid from turmeric suppresses drug metabolizing enzymes like CYP3A4 in liver and is also capable of inducing change in drug transporter P-gp and thus increased the bioavailability of celiprolol and midazolam in rats. The bioenhancer nature of curcumin is similar to piperine. Curcumin suppresses UDP-glucuronyl transferase level in intestine and hepatic tissues. It also modifies the physiological activity in the gastrointestinal tract leading to better absorption of drugs.

\section{Cow Urine}

Cow urine is very effective as a biopotentiers but its distillated form is more used than normal urine. It increases the bioefficacy of antimicrobial, antifungal, and anticancer agents [46]. Cow urine has antitoxic activity itself and if used as augmenting agent with zinc against the cadmium chloride toxicity, it shows miraculous effects. In an experimental study mice treated with cadmium showed zero fertility. But on the other side when a group is treated with cadmium (Anti fertility agent), zinc (Core drug) and cow urine distillate (Biopotentier) showed high fertility index. This indicates that it can be used as a bioenhancer of zinc in cadmium fertility toxicity [47]. It also increases the activity of Rifampicin against Escherichia coli and grampositive bacteria. Mechanism of action of bioenhancing is increased transport across the GIT membrane. The enhancement in transport is approximately 2-7 times. Cow urine distillate enhances both the release an activity gonadotropin releasing hormone (GRH) ultimately increase sperm motility, sperm count, and sperm morphology in male mice [48]. 
Recent Advances of Bioenhancers [49]

\begin{tabular}{|c|c|c|c|c|c|c|c|}
\hline Formulation & \begin{tabular}{|c|} 
Active \\
ingredient
\end{tabular} & Application & $\begin{array}{c}\text { Biological } \\
\text { activity }\end{array}$ & Method of preparation & $\begin{array}{l}\% \text { entrapment } \\
\text { effeciency / size }\end{array}$ & $\begin{array}{c}\text { Route of } \\
\text { administration }\end{array}$ & Ref \\
\hline $\begin{array}{l}\text { Quercetin } \\
\text { Liposome }\end{array}$ & Quercetin & \begin{tabular}{|c|} 
Reduced dose, \\
enhanced penetration \\
in blood brain barrier
\end{tabular} & $\begin{array}{c}\text { Anti-oxidant Anti- } \\
\text { cancer }\end{array}$ & $\begin{array}{l}\text { Reverse evaporation } \\
\text { technique }\end{array}$ & $60 \%$ & Intranasal & {$[50]$} \\
\hline $\begin{array}{c}\text { Liposome } \\
\text { encapsulated } \\
\text { Silymarin }\end{array}$ & Silymarin & $\begin{array}{c}\text { Improve } \\
\text { bioavailability }\end{array}$ & Hepatoprotective & $\begin{array}{l}\text { Reverse evaporation } \\
\text { technique }\end{array}$ & $69.2+-0.6 \%$ & Buccal & {$[51]$} \\
\hline $\begin{array}{l}\text { Rutin-alginate } \\
\text { chitosan } \\
\text { microspheres }\end{array}$ & Rutin & $\begin{array}{c}\text { Targetting into } \\
\text { cardiovascular and } \\
\text { cerebrovascular } \\
\text { system }\end{array}$ & $\begin{array}{l}\text { Cardio-vascular } \\
\text { and cerebro- } \\
\text { vascular }\end{array}$ & $\begin{array}{c}\text { Complex coecervation } \\
\text { method }\end{array}$ & $\begin{array}{c}165-195 \text { (Size in } \\
\mu \mathrm{m})\end{array}$ & In-vitro & {$[52]$} \\
\hline $\begin{array}{c}\text { Zedoary oil } \\
\text { Microspheres }\end{array}$ & Zedoary & $\begin{array}{l}\text { Sustained release and } \\
\text { higher bioavailability }\end{array}$ & Hepato-protective & $\begin{array}{c}\text { Quasi emulsion solvent } \\
\text { diffusion method }\end{array}$ & $\begin{array}{c}100-600 \text { (Size in } \\
\mu \mathrm{m})\end{array}$ & Oral & {$[53]$} \\
\hline $\begin{array}{c}\text { Triptolide } \\
\text { Nanoparticles }\end{array}$ & Triptolide & \begin{tabular}{|c|} 
Enhance the \\
penetration of drug \\
through stratum \\
corneum by increased \\
hydration
\end{tabular} & Anti-inflammatory & $\begin{array}{l}\text { Emulsification } \\
\text { ultrasound }\end{array}$ & & Topical & {$[54]$} \\
\hline $\begin{array}{l}\text { Radix salvia } \\
\text { miltiorrhiza } \\
\text { nanoparticles }\end{array}$ & Radix salvia & $\begin{array}{l}\text { Improve the bio- } \\
\text { availability }\end{array}$ & $\begin{array}{c}\text { Coronary heart } \\
\text { diseases, angina } \\
\text { pectoris and } \\
\text { myocardial } \\
\text { infraction } \\
\end{array}$ & Spray drying technique & $96.68 \%$ & In-vitro & [55] \\
\hline $\begin{array}{c}\text { Capsaicin } \\
\text { Transferosomes } \\
\end{array}$ & Capsaicin & $\begin{array}{l}\text { Increase skin } \\
\text { penetration }\end{array}$ & Analgesic & - & $\begin{array}{c}150.6 \mathrm{~nm} \\
\text { (Droplet size) }\end{array}$ & Topical & {$[56]$} \\
\hline $\begin{array}{c}\text { Colchicine } \\
\text { Transferosomes } \\
\end{array}$ & Colchicine & $\begin{array}{c}\text { Increase skin } \\
\text { penetration }\end{array}$ & Antigout & - & - & In-vitro & {$[57]$} \\
\hline $\begin{array}{c}\text { Ginseng lipid based } \\
\text { systems }\end{array}$ & Flavonoids & Increases absorption & $\begin{array}{l}\text { Nutra-ceutcal } \\
\text { immune } \\
\text { modulator }\end{array}$ & $\begin{array}{l}\text { Phospholipid } \\
\text { complexation }\end{array}$ & $\begin{array}{l}50-100 \mathrm{Mg} \\
\text { (Dose) }\end{array}$ & Oral & {$[58]$} \\
\hline $\begin{array}{l}\text { Greentea lipid } \\
\text { based systems }\end{array}$ & Ginsenoside & Increases absorption & $\begin{array}{c}\text { Nutra-ceutcal, } \\
\text { systemic } \\
\text { antioxidant and } \\
\text { anticancer } \\
\end{array}$ & $\begin{array}{l}\text { Phospholipid } \\
\text { Complexation }\end{array}$ & $\begin{array}{l}50-100 \mathrm{Mg} \\
\text { (Dose) }\end{array}$ & Oral & {$[58]$} \\
\hline
\end{tabular}

Table 3: Herbal NDDS formulations.

\begin{tabular}{|c|c|c|}
\hline US patent No. & Active ingredients & Novel system incorporate \\
\hline US 5948414 & Opioid analgesic and aloe & Nasal spray \\
\hline US 6340478 B1 & Ginsenosides & $\begin{array}{c}\text { Microencapsulated and controlled } \\
\text { release formulations }\end{array}$ \\
\hline Us6890561 B1 & Isoflavones & Microencapsulated formulation \\
\hline US6896898 B1 & Alkaloids of aconitum species & Transdermal delivery system \\
\hline US patent 2005/0142232 A & $\begin{array}{c}\text { Oleaginous oil of Sesamum indicum and } \\
\text { alcoholic extract of Centella asiatica }\end{array}$ & Brain tonic \\
\hline US patent 2007/0042062 A1 & $\begin{array}{c}\text { Glycine max containing 7s globulin } \\
\text { proteinextract,curcumin, Zingiber officinalis }\end{array}$ & Herbal tablet dosage form \\
\hline US patent 2007/0077284A1 & Opioid analgesic (phenanthrene gp) & Transdermal patch \\
\hline US patent 7569236132 & Flavonoids (such as quercetin) and terpenes & Microgranules \\
\hline
\end{tabular}

Table 4: Recent Patents on Herbal Controlled Release Formulations [59]. 


\section{Conclusion}

In developing countries like India cost of treatment is the major concern for modern medicines. Systematic innovative means are needed to reduce these costs. New chemical substances with new modes of action are what modern pharmaceutical research is all about. New drug development technologies are concerned about the economics of drug development. Drug discovery process has been highly aided by Ayurveda through reverse pharmacology with new means of identifying active compounds and reduction of drug development cost. The researchers are now aimed at methods of reduction of drug dosage and thus drug treatment cost making treatment available to a wider section of the society including the financially challenged. This review will be helpful to scientists engaged in research related to bioenhancers of herbal and non- herbal origins.

\section{References}

1. Kalia A N (2006) Textbook of Industrial Pharmacognosy, $1^{\text {st }}$ (Edn.), CBS publishers, pp: 1-3.

2. Jhanwar B, Gupta S (2014) Biopotentiation using Herbs: Novel Technique for Poor Bioavailable Drugs. Int J Pharm Tech Res 6(2): 443-454.

3. Brahmankar DB, Jaiswal S (1995) Biopharmaceutics and Pharmacokinetics: A Treatise. 1st (Edn.) Vallabh Prakashan pp: 24-26.

4. Gopal V, Prakash Yoganandam G, Velvizhi Thilagam T (2016) Bio-enhancer: A Pharmacognostic Perspective. European Journal of Molecular Biology and Biochemistry 3(1): 33-38.

5. Garima Jain, Umesh K Patil (2015) Strategies for enhancement of bioavailability of medicinal agents with natural products. IJPSR 6(12): 5315-5324.

6. Gupta Rajiv, Kesarwani Kritika (2013) Bioavailability enhancers of herbal origin: An overview. Asian Pac J Trop Biomed 3(4): 253-266.

7. Hayton WL (1989) J Pharmacokinet Pharmacodyn 8: 1573-8744.

8. Kang MJ, Cho JY, Shim BH, Kim DK, Lee J (2009) Bioavailability enhancing activities of natural compounds from medicinal plants J Med Plants Res 3(13): 1204-1211.
9. Schinkel AH, Jonker JW (2003) Mammalian drug efflux transporters of the ATP binding cassette (ABC) family: an overview. Adv Drug Deliv Rev 55(1): 3-29.

10. Juliano RL, Ling L (1976) A surface glycoprotein modulating drug permeability in Chinese hamster ovary cell mutants. Biochim Biophys Acta 455(1): 152162.

11. Lundin S, Artursson $P$ (1990) Absorption of a vasopressin analog, 1-deamino-8-D-argininevasopressin (dDAVP), in a human intestinal epithelial cell line, $\mathrm{CaCO}_{2}$. Int J Pharm 64: 181-186.

12. Aungst BJ, Blake JA, Hussain MA (1991) An in vitro evaluation of metabolism and poor membrane permeation impeding intestinal absorption of leucine enkephalin, and methods to increase absorption. J Pharmacol Exp Ther 259(1): 139-145.

13. Schipper NGM, Olsson S, Hoogstraate JA, de Boer AG, Varum KM, Artursson $P$ (1997) Chitosans as absorption enhancers for poorly absorbable drugs 2 : mechanism of absorption enhancement. Pharm Res 14(7): 923-929.

14. Buur A, Bundgaard H, Falch E (1986) Prodrugs of 5Fluorouracil. VII. Hydrolysis Kinetics and Physicochemical Properties of N-Ethoxy- and NPhenoxycarbonyloxymethyl Derivatives of 5Fluorouracil. Acta Pharm Suec 23(4): 205-216.

15. Patel HM, Ryman BE (1976) Oral Administration of Insulin By Encapsulation Within Liposomes. FEBS Lett 62(1): 60-63.

16. Engel RH, Riggi SJ, Fahrenbach MJ (1968) Insulin: Intestinal Absorption as Water-in-Oil-in-Water Emulsions. Nature 219: 856-857.

17. Liversidge GG, Cundy KC (1995) Particle size reduction for improvement of oral bioavailability of hydrophobic drugs: I. Absolute oral bioavailability of nanocrystalline danazol in beagle dogs. Int J Pharm 125: 91-97.

18. Veiga F, Fernandes C, Teixeira F (2000) Oral bioavailability and hypoglycaemic activity of tolbutamide/cyclodextrin inclusion complexes. Int J Pharm 202(1-2): 165-171.

19. Varma MV, Ashokraj Y, Dey CS, Panchagnula R (2003) P-glycoprotein inhibitors and their screening: a perspective from bioavailability enhancement. Pharmacol Res 48(4): 347-359. 
20. Tatiraju DV, Bagade VB, Karambelkar PJ, Jadhav VM, Kadam V (2013) Natural Bioenhancers: An overview. Journal of Pharmacognosy and Phytochemistry 2(3): 55-60.

21. Qazi GN, Bedi KL, Rakesh KJ, Tikoo MK, Tikoo AK, et al. (2009) Bioavailability/Bioefficacy enhancing activity of Cuminm cyminum and extracts and fractions thereof. U.S. Patent US 7514105.

22. Bedi K, Gupta BD, Rakesh KJ, Khan IA, Qazi GN, et al. (2006) Use of herbal agents for potentiation of bioefficacy of anti infectives. U.S. patent US 7119075 B1.

23. SPS. Khanuja, S Kumar, JS Arya, AK Shasany, M Singh, et al. (2000) Composition comprising pharmaceutical/nutraceutical agent and a bioenhancer obtained from Glycyrrhiza glabra. United States Patent, Number 6979471 B1.

24. Imai $\mathrm{T}$, Sakai AM, Ohtake $\mathrm{H}$, Azuma $\mathrm{H}$, Otagiri $\mathrm{M}$ (2005) Absorption-enhancing effect of glycyrrhizin induced in the presence of capric acid. Int J Pharm 294(1-2): 11-21.

25. Qazi GN, Tikoo L, Gupta AK, Ganju K, Gupta DK, et al. (2002) Bioavailability enhancing activity of Zingiber officinale and its extracts/ fractions thereof. European patent EP 1465646.

26. A Ogita, K Fujita, M Taniguchi, T Tanaka (2006) Enhancement of the Fungicidal Activity of Amphotericin B by Allicin, an Allyl-Sulfur Compound from Garlic, against the Yeast Saccharomyces cerevisiae as a Model System. Planta Med 72(13): 1247-1250.

27. Nijveldt RJ, Nood EV, van Hoorn DEC, Boelens PG, Norren K, et al. (2001) Flavonoids: a review of probable mechanisms of action and potential applications. Am J Clin Nutr 74(4): 418-425.

28. Choi JS, Li X (2005) Enhanced diltiazem bioavailability after oral administration of diltiazem with quercetin to rabbits. International Journal of Pharmaceutics 297(12): 1-8.

29. Wang P, Heber D, Henning SM, (2012) Quercetin increased bioavailability and decreased methylation of green tea polyphenols in vitro and in vivo. Food Funct 3(6): 635- 642.
30. JA Vinson, H Al Kharrat, L Andreoli (2005) Effect of Aloe vera preparations on the human bioavailability of vitamins C and E. Phytomed 12(10): 760-765.

31. SPS Khanuja, JS Arya, T Ranganathan, S Kumar, D Saikia, et al. (2003) Nitrile glycoside useful as a bioenhancer of drugs and nutrients, process of its isolation from moringa oleifera. United States Patent, Number 6858588 B2.

32. Kurzer M, Xu X (2003) Dietary phytoestrogens. Annu Review on Nutr 17: 353-381.

33. Sparreboom A, van Asperen J, Mayer U, Schinkel AH, Smit JW, et al. (1997) Limited oral bioavailability and active epithelial excretion of paclitaxel (Taxol) caused by P-glycoprotein in the intestine. Proceedings of National Academic Sciences. 94(5): 2031-2035.

34. Cheng SS, Fu SX, Li YS, Wang NC (1964) The pharmacology of Sabianine A. the analgesic and antiphlogistic actions and acute toxicity. Acta Pharmacologica Sinica 4: 177-180.

35. Liu ZQ, Zhou H, Liu L, Jiang ZH, Wong YF, et al. (2005) Influence of co-administrated sinomenine on pharmacokinetic fate of paeoniflorin in unrestrained conscious rats. J Ethnopharmacol 99(1): 61-67.

36. Bhardwaj RK, Glaeser H, Becquemont L, Klotz U, Gupta SK, et al. (2002) Piperine, a major constituent of black pepper, inhibits human P-glycoprotein and CYP3A4. J Pharmacol Exp Ther 302(2): 645-650.

37. Atal CK, Dubey RK, Singh J (1985) Biochemical basis of enhanced drug bioavailability by piperine: evidence that piperine is a potent inhibitor of drug metabolism. J Pharmacol Exp Ther 232(1): 258-262.

38. Balakrishnan V, Varma S, Chatterji D (2001) Piperine augments transcription inhibitory activity of rifampicin by severalfold in Mycobacterium smegmatis. Current Science 80(10): 1302-1305.

39. Kapil RS, Zutshi U, Bedi KL (1995) Process of preparation of pharmaceutical composition with enhanced activity for treatment of tuberculosis and leprosy. United States Patent Number, US005439891 A.

40. Khan IA, Mirza ZM, Kumar A, Verma V, Qazi GN (2006) Piperine, a phytochemical potentiator of ciprofloxacin against Staphylococcus aureus. Antimicrob Agents Chemother 50(2): 810-812. 
41. Reen RK, Wiebel FJ, Singh J (1997) Piperine inhibits aflatoxin B1-induced cytotoxicity and geno toxicity in V79 Chinese hamster cells genetically engineered to express rat cytochrome P4502B1. J Ethnopharmacol 58(3): 165-173.

42. Selvendiran K, Singh JP, Krishnan KB, Sakthisekaran D (2003) Cytoprotective effect of piperine against benzo[a]pyrene induced lung cancer with reference to lipid peroxidation and antioxidant system in albino mice. Fitoterapia 74(1-2): 109-115.

43. Choi BM, Kim SM, Park TK, Li G, Hong SJ, et al. (2007) Piperine protects cisplatin-induced apoptosis via heme oxygenase-1 induction in auditory cells. J Nutr Biochem 18(9): 615- 622.

44. Majeed M, Badmaev V, Rajendran R (1996) Use of piperine to increase bioavailability of nutritional compounds. United States Patent Number, US005536506 A.

45. Badmaev V, Majeed M, Norkus EP (1999) Piperine, an alkaloid derived from black pepper increases serum response of beta-carotene during 14-days of oral betacarotene supplementation. Nutrition Research 19(3): 381-388.

46. Kekuda TRP, Nishanth BC, Kumar SVP, Kamal D, Sandeep M, et al. (2010) Cow urine concentrate: a potent agent with antimicrobial and anthelmintic activity. Journal of Pharmacy Research 3: 1025-1027.

47. Khan A, Srivastava VK (2005) Antitoxic and bioenhancing role of kamdhenu ark (cow urine distillate) on fertilitty rate of male mice (Mus musculus) affected by cadmium chloride toxicity. International Journal of Cow Science 1(2): 43-46.

48. Ganaie JA, Shrivastava VK (2010) Effects of gonadotropin releasing hormone conjugate immunization and bioenhancing role of Kamdhenu ark on estrous cycle, serum estradiol and progesterone levels in female Mus musculus. Iranian Journal of Reproductive Medicine 8(2): 70-75.

49. Kesarwani Kritika, Gupta Rajiv (2013) Bioavailability enhancers of herbal origin: An overview. Asian Pac J Trop Biomed 3(4): 253-266.
50. Ajazuddin, Saraf S (2008) Applications of novel drug delivery system for herbal formulations. Nanomed Nanotechnol Biol Med 4: 70-78.

51. Samaligy MS, Afifi NN, Mahmoud EA (2006) Evaluation of hybrid liposomes-encapsulated silymarin regarding physical stability and in vivo performance. Int J Pharm 319(1-2): 121-129.

52. Xiao L, Zhang YH, Xu JC, Jin XH (2008) Preparation of floating rutinalginate- chitosan microcapsule. Chine Trad Herb Drugs 2: 209-212.

53. You J, Cui F, Han X, Wang Y, Yang L, et al. (2006) Study of the preparation of sustained-release microspheres containing zedoary turmeric oil by the emulsionsolvent-diffusion method and evaluation of the selfemulsification and bioavailability of the oil. Colloids Surf B 48(1): 35-41.

54. Mei Z, Chen H, Weng T, Yang Y, Yang X (2003) Solid lipid nanoparticle and microemulsion for topical triptolide. Eur J Pharm Biop Harm 56(2): 189-196.

55. Su YL, Fu ZY, Zhang JY, Wang WM, Wang H, et al. (2008) Microencapsulation of Radix salvia miltiorrhiza nanoparticles by spray-drying. Powder Technol 184: 114-121.

56. Xiao YL, Luo JB, Yan ZH, Rong HS, Huang WM (2006) Preparation and invitro and invivo evaluations of topically applied capsaicin transferosomes. Yao Xeu Xeu Bao 41(5): 461-466.

57. Singh HP, Utreja P, Tiwary AK, Jain S (2009) Elastic liposomal formulation for sustained delivery of colchicine: in vitro characterization and in vivo evaluation of anti-gout activity. AAPSJ 11(1): 54-64.

58. Bhattacharya S, Ghosh A (2009) Phytosomes: the emerging technology for enhancement of bioavailability of botanicals and nutraceuticals. Inter. J Aes Anti Med 2(1): 225-229.

59. Goyal A, Kumar S, Nagpal M, Singh I, Arora S (2011) Potential of novel drug delivery systems for herbal drugs. Ind J Pharma Edu Res 45(3): 225-235. 